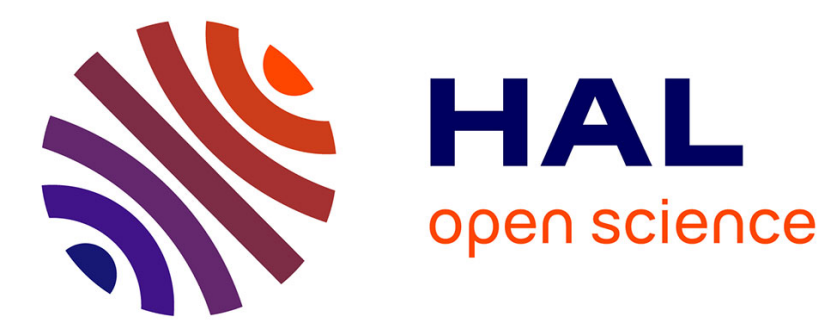

\title{
Finite element models of the thigh-buttock complex for assessing static sitting discomfort and pressure sore risk
}

\author{
Léo Savonnet, Xuguang Wang, Sonia Duprey
}

\section{To cite this version:}

Léo Savonnet, Xuguang Wang, Sonia Duprey. Finite element models of the thigh-buttock complex for assessing static sitting discomfort and pressure sore risk. Computer Methods in Biomechanics and Biomedical Engineering, 2018, 21 (4), pp. 379-388. 10.1080/10255842.2018.1466117 . hal-02089166

\section{HAL Id: hal-02089166 https://hal.science/hal-02089166}

Submitted on 3 Apr 2019

HAL is a multi-disciplinary open access archive for the deposit and dissemination of scientific research documents, whether they are published or not. The documents may come from teaching and research institutions in France or abroad, or from public or private research centers.
L'archive ouverte pluridisciplinaire HAL, est destinée au dépôt et à la diffusion de documents scientifiques de niveau recherche, publiés ou non, émanant des établissements d'enseignement et de recherche français ou étrangers, des laboratoires publics ou privés. 
SAVONNET, Léo, WANG, Xuguang, DUPREY, Sonia, 2018, Finite element models of the thigh-buttock complex for assessing static sitting discomfort and pressure sore risk: a literature review, Computer Methods in Biomechanics and Biomedical Engineering, 21, 4, Taylor \& Francis Ltd, pp. 379-388, DOI: 10.1080/10255842.2018.1466117

Finite element models of the thigh-buttock complex for assessing static sitting discomfort and pressure sore risk

Léo Savonnet ${ }^{1}$, Xuguang Wang $^{1}$, Sonia Duprey ${ }^{1}$

${ }_{1}$ Université de Lyon, Université Claude Bernard Lyon 1, IFSTTAR, Lyon, France

${ }_{2}$ Service de radiologie, Centre hospitalier Lyon-Sud, Lyon, France.

Corresponding author: Sonia Duprey,

IFSTTAR, 25 Avenue François Mitterrand, 69500 Bron

sonia.duprey@ifsttar.fr

0478656882

Abstract

Being seated for long periods, while part of many leisure or occupational activities, can lead to discomfort, pain and sometimes health issues. The impact of prolonged sitting on the body has been widely studied in the literature, with a large number of human-body finite element models developed to simulate sitting and assess seat-induced discomfort or to investigate the biomechanical factors involved.

Here, we review the finite element models developed to investigate sitting discomfort or risk of pressure sores. Our study examines finite element models from twenty-seven papers, seventeen dedicated to assessing seating discomfort and ten dedicated to investigating pressure ulcers caused by prolonged sitting. The models' mesh composition and material properties are found to differ widely. These models share a lack of validation and generally make little allowance for anthropometric diversity.

Highlights

- Literature review focusing on finite element models assessing sitting discomfort and pressure ulcer risk due to prolonged sitting 


\section{Introduction}

Being seated for long periods is common in modern societies, either for leisure or occupational activities or due to mobility impairments. However, long-term sitting may lead to sitting discomfort (De Looze et al. 2003; Vink \& Hallbeck 2012a; Hiemstra-van Mastrigt et al. 2017), and even to pressure sores for people confined to a wheelchair (Olesen et al. 2010a).

Investigations of the causes of sitting discomfort (Harrison et al. 1999; Vink 2011; Zemp et al. 2015) show that, while the perception of discomfort can be influenced by psychological factors, biomechanical causes are paramount (Moes et al. 2002; De Looze et al. 2003; Vink \& Hallbeck 2012b). The source of sitting discomfort most frequently cited in the literature is compression of the buttock-thigh soft tissues (Kamijo et al. 1982; Oudenhuijzen et al. 2003; De Looze et al. 2003; Kolich 2004; Mergl et al. 2004a) at specific locations (e.g. the ischial tuberosity or the sacrum). This compression leads to extensive deformation of the different layers of soft tissues (Linder-Ganz et al. 2007a; Al-Dirini et al. 2015), thus limiting blood circulation. As a result, the quantity of oxygen in the tissue is reduced (Olesen et al. 2010b), inducing discomfort (Al-Dirini et al. 2015). Several discomfort criteria based on seat contact pressure were proposed in the literature. De Looze et al. (2003) analyzed 21 studies and showed that contact pressure distribution is the variable best correlated with discomfort ratings. Several studies defined a maximum pressure value as a discomfort threshold based on physiological observations. For instance, Ciaccia \& Sznelwar (2012) and Conine et al. (1994) suggested the thresholds of $4.25 \mathrm{kPa}$ and $7.8 \mathrm{kPa}$ as limits above which capillaries could be obstructed and oxygen in the tissues could be deprived. Sember J (1994) showed from in vivo experiments that a pain threshold was reached after 30 minutes at a pressure of $55 \mathrm{kPa}$, whereas discomfort was perceived after 15 minutes at a pressure of $6.9 \mathrm{kPa}$. He also found that capillary obstruction could lead to skin cell death (necrosis) when pressure exceeded $6.89 \mathrm{kPa}$. Jackson et al. (2009) found no perception of discomfort when subjects remained immobile at pressures below $8.8 \mathrm{kPa}$. 
The capacity of the soft tissue to support the load depends on the location of pressure. For example, Kamijo et al. (1982) found different pressure thresholds depending on the location (5.8 $\mathrm{kPa}$ under the ischia; $2.9 \mathrm{kPa}$ under the thighs), consistent with Chen, J. et al. (2007) who showed that pressure should be highest underneath the ischial tuberosities and should dissipate toward the thighs and sides. Most studies chose to consider the overall pressure distribution on the seat pan for defining the discomfort criterion (Kamijo et al. 1982; Kolich 2004; Oudenhuijzen et al. 2003). However, some studies divided the seat pan into different parts, like front thigh, mid-thigh and buttocks. Thresholds in terms of load for different parts of the thighs and buttocks were experimentally defined by Hartung (2006) and Mergl (2005) based on in vivo experiments on 20 participants. For example, according to Mergl suggested that between $50 \%$ and $65 \%$ of the total load on the seat pan should be supported by the buttocks, less than $14 \%$ by the middle of the thigh and less than $6 \%$ by the front of the thigh. Mergl also studied the pressure gradient, concluding that pressure gradient should not exceed $5.6,1.6$ and $0.5 \mathrm{kPa} / \mathrm{mm}$ respectively under the buttocks, the thighs and the front of the thighs. In terms of maximal pressure at the seat interface, Mergl suggested 20 and $7 \mathrm{kPa}$ respectively for the buttocks and the thighs. However, these thresholds were based on subjective discomfort evaluation by the participants involved in the experiments, and should be taken with caution. Although standardization methods (shifting and stretching discomfort rating curves) and the exclusion of no significant relationship between pressure and discomfort were used to eliminate inter-participant variations in discomfort assessment, external factors like environment, psychological state or fatigue can influence such ratings.

Predicting the risk of pressure sores mainly depends on the physiological and mechanical sub-dermal tissue conditions (Olesen et al. 2010a). The pressure at the interface is easily measured and can be an efficient discomfort indicator. However, interface pressure cannot reveal mechanical sub-dermal tissue conditions (Oomens et al. 2010). For example, the location of maximal pressure greatly differs between surface and sub-dermal tissues (Silber \& Then 2009). Soft tissue internal strain depends on the internal anatomy and are not only linked to external pressure. One study 
(Luboz et al. 2017) developed an algorithm to predict internal strain from external pressure, based on reduced-order modeling techniques (ROM); however it requires subject-specific geometry. Some authors maintain that strain degrades the soft tissue cells more than pressure or stress. The most common theory is that compressive strain causes occlusion of capillary blood flow, resulting in local ischemia (Kosiak 1961; K Daniel et al. 1981). However, ischemia is not the only phenomenon causing cell damage. Loerakker et al. (2011) showed in rats that deformations of the muscle cells directly cause muscle damage that can be greater than the damage from ischemia triggered by limiting blood flow in the cells. Reddy et al. (1981) hypothesized that an accumulation of metabolic waste products due to the occlusion of the lymphatic system when cells are compressed may result in cell damage. These physiological phenomena induced by deformation lead to pressure ulcers. Several experiments were performed on animals to define the link between deformation level and cell damage. For example, Gawlitta et al. (2006) found that a compression of $40 \%$ leads to $10 \%$ cell death in 2 hours and $60 \%$ cell death within 22 hours. Breuls et al. (2003) described similar findings, with $13.6 \%$ of muscle tissue cells dying after a 50\% gross compressive strain level. Gefen et al. (2008) showed that cells were strain-tolerant for only one hour under a strain of $50 \%$.

Thus, the strain applied to soft tissue causes ischemia and cell degradation, leading first to discomfort and later to cell necrosis and pressure ulcers. In fact, feeling discomfort in the buttocks can be considered as a preliminary stage of pressure ulcers. Consequently, soft tissue strain needs to be investigated even more than external pressure.

Numerical simulation using human models offers an alternative to experiments for assessing sitting discomfort. While experiments are expensive and time-consuming, numerical models can provide fast results at little cost. Most importantly, they can estimate parameters that are not easy to measure, such as internal stresses and strains in the soft tissues. However, while extensive research has been conducted to develop finite element $(\mathrm{FE})$ models estimating sitting discomfort, to the authors' knowledge there is no review focusing on FE models used for sitting discomfort. 
The aim of this study, therefore, is to review FE models developed for sitting applications. Since the same mechanical mechanisms are at work at different levels in both sitting discomfort and pressure ulcers, the review covers FE models assessing both discomfort and pressure ulcer formation.

\section{Overview of FE models for investigating sitting}

\subsection{Literature search}

A systematic literature review was performed from 3 databases, Science direct, Web Of Knowledge and PubMed, chosen for their comprehensiveness in the scientific and clinical fields. The search used the following keywords in the title: (finite element OR model) AND (*comfort OR pressure ulcer OR seat OR sitting) and the following keywords in the topics: finite element AND *comfort AND seat.

The search returned 178 results (including repetitions), which were analyzed to remove irrelevant publications not including FE model development details and duplicate articles. The references of the publications selected were analyzed for additional articles to add to the initial search results. In the end, 27 papers were selected (Figure 1): 17 papers describing the development of an FE model dedicated to sitting comfort evaluation (Table 1) and 10 papers describing the development of an FE model dedicated to investigating pressure ulcer formation (Table 2).

\subsection{Mesh composition and geometry of the models}

From our total list of models, two main categories of FE model can be identified: planar and volumetric models. The planar models comprise one thin (1-4 centimeters) anatomical slice in the frontal plane at the location of the ischia. These models are dedicated to soft tissue strain or stress estimation. The volumetric models are 3D representations of the anatomical parts. These models are dedicated to tissue stress and strain and/or contact pressure estimation. Most of the models dedicated to sitting discomfort (15 over 17) are volumetric models, since they focus on contact 
pressure estimation. Conversely, most of the models (8 out of 10 ) dedicated to pressure ulcers are planar models, focusing mainly on internal stress estimation under the ischia in the sagittal plane. Only a few of the volumetric models (6 out of 17 ) represent the whole human body (studies $5,7,12$, 15 and 16 in Table 1). The majority of the proposed models are limited to the upper leg and buttocks $(3,4,6)$.

The models' mesh composition in terms of soft tissues is as follows: 14 models merge all the soft tissues together, 4 differentiate the skin from the other tissues (muscles and fat) and 11 differentiate the muscles from the fat tissue (Table 1, Table 2).

The sources used to create geometric models are: 8 models from MRI images, 5 from CT-scan images, 3 from pictures of human slices (from the Visible Human Project or the European HUMOS project), 5 from geometric databases (3dcadbrowser, Poser and Human Builder) and 1 from 3D laser scans. Most of the models represent approximately $50^{\text {th }}$ percentile males and only 4 studies develop 2 or more models representing different body sizes. Model geometries mainly rely on a single source $(4,7,11,12,13,14,18,21,24,26,27$ in Tables 1-2), although a few models use different sources for the soft tissues and the bones. Bones are either obtained by CT-scans $(3,27)$ or MRI $(11,17,21,22$, $24,26)$, and skin derived either from a CT-scan of another subject $(2,3,5)$ or of the same subject (23), or from a database like CEASAR (6) or 3dcadbrowser (http://www.3dcadbrowser.com/).

Several models use MRI images from a seated subject $(1,11,17,21,25,26)$ or from a subject in a posture close to sitting (22). However, most use images of a subject lying down and adapt the model posture afterwards $(4,7,8,12,13)$. Finally, most of the models with detailed soft tissues (muscles differentiated from fat and skin) are generated from MRI images, while less detailed models are based on external anthropometric dimensions only. These detailed models are mainly dedicated to clinical applications (evaluation of pressure sore risk). The models without a detailed representation of the soft tissues are dedicated to automotive applications (seating discomfort evaluation) and seat pressure estimation. 


\subsection{Material properties}

In most of the models, bones are considered as rigid bodies $(2,3,4,5,7,8,9,13,21,22,26$, 27). In some cases, a linear elastic law is used but with a large Young's Modulus $(1,6,11,12,14,15$, $16,25)$ and a Poisson's ratio of 0.3 or $0.49(11)$.

Soft tissues are modeled using 5 different laws for the mechanical properties of muscles and fat tissue: a Mooney Rivlin law (9 out of 27), a Neo-Hookean law (7 out of 27), a generalized Mooney Rivlin law (2 out of 27), an Ogden law ( 3 out of 27 ) and an elastic linear law (5 out of 27) (Table 3). Used most frequently, the Mooney Rivlin law (Eq 1) (Mooney 1940; Rivlin 1948) describes a hyperelastic isotropic material through a strain energy function (Eq 1), where $J_{1}, J_{2}, J_{3}$ are the invariants of the right Cauchy-Green strain tensor and the material parameters $A_{3}$ and $A_{4}$ are functions of the coefficients $A_{1}$ and $A_{2}$.

$$
W=A_{1}\left(J_{1}-3\right)+A_{2}\left(J_{2}-3\right)+A_{3}\left(J_{3}^{-2}-1\right)+A_{4}\left(J_{3}-1\right)^{2} \quad(\text { Eq } 1)
$$

Verver (4) proposes A1 and A2 from a range of values used in previous FE models (Chow \& Odell 1978; Bosboom et al. 2001; Oomens et al. 2003). Subsequently, the proposed parameters are used in other models $(6,7,8,12,13,15,16,22)$. Only Grujicic et al (2009a) identifies the values of these parameters by an optimization procedure (inverse method) based on experimental indentation test data from Zhang et al. (1997).

The generalized Mooney Rivlin law (or polynomial hyperelastic law) (Eq 2) at the second order is used by Tang et al. (2010b) and Mohanty \& Mahapatra (2014) with parameters determined from indentation tests performed by Tang \& Tsui (2006).

$$
W=\sum_{i, j=0}^{n} C_{i j}\left(I_{1}-3\right)^{i}\left(I_{2}-3\right)^{j}+\sum_{k=1}^{m} D_{k}(J-1)^{2 k}
$$


For the models using a Neo-Hookean law (a special case of the Mooney Rivlin law with $\mathrm{C}_{01}=0$, Eq 3), the parameter $C_{1}$ is identified from a variety of experimental data. Moes et al. (2002) use an inverse method to find $C_{1}$ based on experimental stresses. Lin et al. (2004) use parameters based on an experimental study performed by Larrabee (1986). Brosh \& Arcan (2000b) and Linder-Ganz et al. (2007b) find parameters through indentation tests. Levy (2014) uses values from in vitro indentation tests performed on skin and fat tissues from sheep by Gefen \& Haberman (2007) and on fresh porcine muscles by Palevski et al. (2006). Luboz et al. (2014) use an inverse method based on the internal strain calculated in previous numerical studies (Oomens et al. 2003; Linder-Ganz et al. 2007b). The different values used vary widely, from 1 to $95 \mathrm{kPa}$.

$$
W=C_{1}=\left(I_{1}-3\right) \quad(\text { Eq } 3)
$$

The Ogden hyperelastic law (Eq 4, where strain energy density is expressed in terms of principal stretches $\lambda_{\mathrm{j}}$ ) is used by Li et al. (2013) at the second order for the fat tissue and by Oomens et al. (2013a) and by Al-Dirini et al. (2016) at the first order.

$$
W\left(\lambda_{1}, \lambda_{2}, \lambda_{3}\right)=\sum_{p=1}^{N} \frac{\mu_{p}}{\alpha_{p}}\left(\lambda_{1}^{\alpha_{p}}+\lambda_{1}^{\alpha_{p}}+\lambda_{1}^{\alpha_{p}}-3\right)(\mathrm{Eq} 4)
$$

Oomens et al. (2013b) and Al-Dirini et al. (2016) optimize parameters until simulations match experiments, whereas Li et al. (2013) do not explain the source of their parameters.

Finally, a simple linear elastic law is used in a few models $(3,14,18,20$ and 23$)$. The value for the Young's modulus comes from a variety of experimental indentation tests (Zheng \& Mak 1999, Hartung et al. 2004, Todd \& Thacker 1994). Values can vary widely, between 1 and $64.8 \mathrm{kPa}$.

A Poisson's coefficient of 0.49 is always used to simulate the incompressibility of the soft tissues. The skin is often modeled using a linear elastic law with a Young's modulus of $0.15 \mathrm{MPa}(4,8$, 12) or $0.85 \mathrm{MPa}(6)$. 


\subsection{Simulations and Validation}

For simulations, the boundary conditions involve either 1 ) applying gravity on the body to reach the fixed seat (20 out of 27 ) or 2 ) applying a load or moving the seat to a fixed human model (7 out of 27). The first type of boundary condition is applied to whole body models $(5,7,8,12,15)$ and to models limited to the upper leg and buttocks, by applying the upper body weight either on the ischial tuberosities of the pelvis $(9,11,14,18)$ or on the whole pelvis $(4,10,13,23,24,26)$. The weight of the lower leg is applied on the femur $(4,9,14)$. A displacement observed experimentally may also be reproduced on the ischial tuberosity $(1,20,25)$ to simulate crushing the foam of the seat . For the second type of boundary condition, the load applied on the seat is either the body weight $(2,3)$ or a measured pressure $(19,22,27)$. The femur is usually fixed at its extremities in the frontal direction and the lower trunk is fixed in the vertical direction. Linder-Ganz et al. (2007b) and Al-Dirini et al. (2016) apply a displacement measured on MRI images. Concerning positioning, the initial body posture was not specified in the reviewed studies when the whole body models were positioned by the gravity. When the model is partial and replicates an experiment, the measured bone position is applied to the model. However, in most studies the real position is unknown and the model positioning is not specified.

Very few studies include a validation process. Only 6 out of the 13 models for discomfort (and thus contact pressure) assessment compare simulated peak or average pressure with experimental observations (Table 4). Large differences can be found between models, with maximal pressure prediction error varying from $2 \%$ (Mergl et al. 2004b) to 37\% (Verver et al. 2004a). Of the models dedicated to pressure sore risk evaluation (and thus internal strain prediction) (14), only 4 studies estimate an error in deformation between simulations and experimental observations, either from MRI (Todd \& Thacker 1994; Makhsous et al. 2007a; Al-Dirini et al. 2016) or from X-ray images (Wagnac et al. 2008a). Todd \& Thacker (1994) calculate the soft tissue displacement in one plane under the ischial tuberosities of loaded buttocks. Wagnac et al. (2008b) measure the displacement of radio-opaque landmarks placed on the skin. Makhsous et al. (2007) estimate the displacement of 30 
regions of interest identified on the soft tissues. Al-Dirini et al. (2016) calculate the quadratic mean error between the deformed and non-deformed surface of the gluteus muscle. Consequently, only two studies compare the simulated soft tissue internal deformations in $3 \mathrm{~d}$ with experimental data.

\section{Discussion}

The objectives of the current study were to review the existing FE models of the thigh-buttocks complex dedicated to sitting biomechanics.

Extensive effort has been devoted over the past two decades to developing FE models for sitting simulation. However, our review shows that these models involve very disparate material properties or soft tissue components, and that no consensus on these modeling choices is possible due to lack of validation.

27 FE models developed after 1004 were selected for review in this paper, 17 dedicated to sitting discomfort assessment and 10 dedicated to clinical pressure sores induced by static sitting. Of the 27,6 were whole-body models. Of the remaining 21 models, 11 only represented the thighbuttock complex while 10 integrated only a $2 \mathrm{~d}$ slice of the thigh. Large discrepancies in soft tissue representation among the 27 studies selected were observed. Some models represented the soft tissues as one single component, while others differentiated between skin, fat and muscles. In the most complex models (Linder-Ganz et al. 2007a; Makhsous et al. 2007b; Al-Dirini et al. 2016), muscles were represented individually. These differences can be explained by the intended applications: the detailed models (9 out of 27) were mainly developed to estimate internal stresses in the tissues for clinical applications, focusing on the area under the ischial tuberosities (anatomical slice). Their geometry was mainly based on MRI images (8 out of 14). Contrastingly, models developed for sitting discomfort investigation (13 over 27 ) included the whole thigh-buttock complex and represented the soft tissues as a whole (11 over 13); their geometry was derived mainly from databases. 
Regarding the material properties of soft tissues, very diverse laws and parameters were used. The laws most commonly used were the elastic linear, Neo-Hookean or Mooney Rivlin laws. The material parameters came from many different experimental studies, apart from the parameters used in the models based on Mooney Rivlin law, all of which came from (Verver et al. 2004a). The wide variety of material laws applied may reflect the varying applications and purposes of the models. However, even for models with the same purpose, material laws differed greatly among studies. Even more surprisingly, material parameters could be multiplied by almost a factor of 100 . Since most of the studies did not include a validation process, it is hard to evaluate which parameters are the most appropriate.

One interesting avenue for future research would be to investigate the effect of the different modeling options (soft tissue representation, material law, material parameters) on model outputs via a large sensitivity study covering parameters such as mesh composition and material properties. To find the optimal mesh composition and soft tissue material property, this sensitivity analysis should be performed in conjunction with experimental data collection (external pressure and internal deformation) to assess the accuracy of the models. This would enable an optimal set of "modeling options" to be defined for the further development of thigh-buttocks FE models. It is also noteworthy that only a few models were validated with experimental observations, since most of the models were not subject-specific and thus their results could not be compared to observations from subjects. Most of the models represent one specific population category (usually the $50^{\text {th }}$ male percentile) or cover several representative population categories (Pankoke \& Siefert 2007). However as a seat is designed for differently sized people, FE models should be able to represent large variation of body dimensions. Many studies (e.g. Mastrigt et al. (2017)) showed that contact pressure depended on the anthropometry. Consequently, future studies should either develop a parametric model able to represent the wide range of variation in sitters' anthropometry, or use a personalizing tool like the Piper software developed by IFFSTAR (Beillas et al. 2015) to scale a generic model to any anthropometry. 
Finally, these studies are based on the assumption that pressure is the factor leading to discomfort. However, the relation between discomfort and pressure is still not fully demonstrated, with few studies exploring this issue. Moreover, researchers increasingly report that it is strain, rather than pressure or stress, which principally causes discomfort. Although strain thresholds exist for cell necrosis, the relation between strain and discomfort has not yet been established. Consequently, more research is needed to address the link between soft tissue deformations and feelings of discomfort.

\section{Acknowledgement}

This study was partially supported by ZODIAC Seat France. 


\section{References}

Al-Dirini RMA, Reed MP, Hu J, Thewlis D. 2016. Development and Validation of a High Anatomical Fidelity FE Model for the Buttock and Thigh of a Seated Individual. Ann Biomed Eng. 44:2805-2816.

Al-Dirini RMA, Reed MP, Thewlis D. 2015. Deformation of the gluteal soft tissues during sitting. Clin Biomech. 30:662-668.

Bar. 1998. Pressure: Why measure it and how. Present 14th Int Seat Symp.

Beillas P, Petit P, Kleiven S, Kirscht S, Chawla A, Jolivet E, Faure F, Praxl N, Bhaskar A. 2015. Specifications of a software framework to position and personalise human body models. In: DIVA [Internet]. [place unknown]: International Research Council on the Biomechanics of Injury; [cited 2018 Feb 8]; p. 594-595. Available from: http://urn.kb.se/resolve?urn=urn:nbn:se:kth:diva-202905

Bosboom EMH, Hesselink MKC, Oomens CWJ, Bouten CVC, Drost MR, Baaijens FPT. 2001. Passive transverse mechanical properties of skeletal muscle under in vivo compression. J Biomech. 34:1365-1368.

Breuls RGM, Bouten CVC, Oomens CWJ, Bader DL, Baaijens FPT. 2003. Compression Induced Cell Damage in Engineered Muscle Tissue: An In Vitro Model to Study Pressure Ulcer Aetiology. Ann Biomed Eng. 31:1357-1364.

Brosh T, Arcan M. 2000. Modeling the body/chair interaction - an integrative experimentalnumerical approach. Clin Biomech. 15:217-219.

Chen, J., J. Hong, E. Zhang, J. Liang. 2007. Body Pressure Distribution of Automobile Driving Human Machine Contact Interface.". Chin J Mech Eng. 20:66-70.

Cheng Z, Smith JA, Pellettiere JA, Fleming SM. 2007. Considerations and Experiences in Developing an FE Buttock Model for Seating Comfort Analysis [Internet]. Warrendale, PA: SAE International; [cited 2015 Apr 24]. Available from: http://papers.sae.org/2007-01-2458/

Choi HY, Kim KM, Han J, Sah S, Kim S-H, Hwang S-H, Lee KN, Pyun J-K, Montmayeur N, Marca C, et al. 2007. Human Body Modeling for Riding Comfort Simulation. In: Duffy VG, editor. Digit Hum Model [Internet]. [place unknown]: Springer Berlin Heidelberg; [cited 2015 Apr 24]; p. 813-823. Available from: http://link.springer.com/chapter/10.1007/978-3-54073321-8_92

Chow WW, Odell El. 1978. Deformations and Stresses in Soft Body Tissues of a Sitting Person. J Biomech Eng. 100:79-87.

Ciaccia FRDAS, Sznelwar LI. 2012. An approach to aircraft seat comfort using interface pressure mapping. Work J Prev Assess Rehabil. 41:240-245.

Conine TA, Hershler C, Daechsel D, Peel C, Pearson A. 1994. Pressure ulcer prophylaxis in elderly patients using polyurethane foam or Jay wheelchair cushions. Int J Rehabil Res Int Z Für Rehabil Rev Int Rech Réadapt. 17:123-137.

De Looze MP, Kuijt-Evers LFM, Van DieëN J. 2003. Sitting comfort and discomfort and the relationships with objective measures. Ergonomics. 46:985-997. 
Gawlitta D, Li W, Oomens CWJ, Baaijens FPT, Bader DL, Bouten CVC. 2006. The Relative Contributions of Compression and Hypoxia to Development of Muscle Tissue Damage: An In Vitro Study. Ann Biomed Eng. 35:273-284.

Gefen A, Haberman E. 2007. Viscoelastic properties of ovine adipose tissue covering the gluteus muscles. J Biomech Eng. 129:924-930.

Gefen A, van Nierop B, Bader DL, Oomens CW. 2008. Strain-time cell-death threshold for skeletal muscle in a tissue-engineered model system for deep tissue injury. J Biomech. 41:2003-2012.

Grujicic M, Pandurangan B, Arakere G, Bell WC, He T, Xie X. 2009a. Seat-cushion and softtissue material modeling and a finite element investigation of the seating comfort for passenger-vehicle occupants. Mater Des. 30:4273-4285.

Grujicic M, Pandurangan B, Arakere G, Bell WC, He T, Xie X. 2009b. Seat-cushion and softtissue material modeling and a finite element investigation of the seating comfort for passenger-vehicle occupants. Mater Des. 30:4273-4285.

Guo L-X, Dong R-C, Zhang M. 2016. Effect of lumbar support on seating comfort predicted by a whole human body-seat model. Int J Ind Ergon. 53:319-327.

Harrison DD, Harrison SO, Croft AC, Harrison DE, Troyanovich SJ. 1999. Sitting biomechanics Part I: Review of the Literature. J Manipulative Physiol Ther. 22:594-609.

Hartung. 2006. Objektivierung des statischen Sitzkomforts auf Fahrzeugsitzen durch die Kontaktkräfte zwischen Mensch und Sitz, Dissertation am Lehrstuhl für Ergonomie, Technische Universität München.

Hiemstra-van Mastrigt S, Groenesteijn L, Vink P, Kuijt-Evers LFM. 2017. Predicting passenger seat comfort and discomfort on the basis of human, context and seat characteristics: a literature review. Ergonomics. 60:889-911.

Huang S, Zhang Z, Xu Z, He Y. 2015. Modeling of human model for static pressure distribution prediction. Int J Ind Ergon. 50:186-195.

Jackson C, Emck AJ, Hunston MJ, Jarvis PC. 2009. Pressure Measurements and Comfort of Foam Safety Cushions for Confined Seating. Aviat Space Environ Med. 80:565-569.

K Daniel R, L Priest D, C Wheatley D. 1981. Daniel R K, Priest D L, Wheatley D CEtiologic factors in pressure sores: An experimental model. Arch Phys Med Rehabil 62: 492-498. Arch Phys Med Rehabil. 62:492-8.

Kamijo, Tsujimura, Obara, Katsumata. 1982. Evaluation of seating comfort. SAE Conf.

Kolich. 2004. Predicting automobile seat comfort using a neural network. Int J Ind Ergon 33.:285-293.

Kosiak M. 1961. Etiology of decubitus ulcers. Arch Phys Med Rehabil. 42:19-29.

Kuroda S, Akimoto M. 2005. Finite element analysis of undermining of pressure ulcer with a simple cylinder model. J Nippon Med Sch Nippon Ika Daigaku Zasshi. 72:174-178.

Larrabee WF. 1986. A finite element model of skin deformation. I. Biomechanics of skin and soft tissue: a review. The Laryngoscope. 96:399-405. 
Levy A, Kopplin K, Gefen A. 2014. An air-cell-based cushion for pressure ulcer protection remarkably reduces tissue stresses in the seated buttocks with respect to foams: Finite element studies. J Tissue Viability. 23:13-23.

Li S, Zhang Z, Wang J. 2013. A New Custom-Contoured Cushion System Based on Finite Element Modeling Prediction. J Mech Med Biol. 13.

Lin F, Moran B, Bankard J, Hendrix R, Makhsous M. 2004. FEM model for evaluating buttock tissue response under sitting load. Conf Proc Annu Int Conf IEEE Eng Med Biol Soc IEEE Eng Med Biol Soc Annu Conf. 7:5088-91.

Linder-Ganz E, Shabshin N, Itzchak Y, Gefen A. 2007a. Assessment of mechanical conditions in sub-dermal tissues during sitting: A combined experimental-MRI and finite element approach. J Biomech. 40:1443-1454.

Linder-Ganz E, Shabshin N, Itzchak Y, Gefen A. 2007b. Assessment of mechanical conditions in sub-dermal tissues during sitting: A combined experimental-MRI and finite element approach. J Biomech. 40:1443-1454.

Loerakker S, Manders E, Strijkers GJ, Nicolay K, Baaijens FPT, Bader DL, Oomens CWJ. 2011. The effects of deformation, ischemia, and reperfusion on the development of muscle damage during prolonged loading. J Appl Physiol Bethesda Md 1985. 111:1168-1177.

Luboz V, Bailet M, Boichon Grivot C, Rochette M, Diot B, Bucki M, Payan Y. 2017. Personalized modeling for real-time pressure ulcer prevention in sitting posture. J Tissue Viability.

Luboz V, Petrizelli M, Bucki M, Diot B, Vuillerme N, Payan Y. 2014. Biomechanical modeling to prevent ischial pressure ulcers. J Biomech. 47:2231-2236.

Makhsous M, Lim D, Hendrix R, Bankard J, Rymer WZ, Lin F. 2007a. Finite Element Analysis for Evaluation of Pressure Ulcer on the Buttock: Development and Validation. IEEE Trans Neural Syst Rehabil Eng. 15:517-525.

Makhsous M, Lim D, Hendrix R, Bankard J, Rymer WZ, Lin F. 2007b. Finite Element Analysis for Evaluation of Pressure Ulcer on the Buttock: Development and Validation. IEEE Trans Neural Syst Rehabil Eng. 15:517-525.

Mastrigt SH, Groenesteijn L, Vink P, Kuijt-Evers LFM. 2017. Predicting passenger seat comfort and discomfort on the basis of human, context and seat characteristics: a literature review. Ergonomics. 60:889-911.

Mergl. 2005. Predicting Long Term Riding Comfort in Cars by Contact Forces Between Human and Seat [Internet]. [cited 2016 Feb 5]. Available from: http://papers.sae.org/2005-01$2690 /$

Mergl C, Anton T, Madrid-Dusik R, Hartung J, Librandi A, Bubb H. 2004a. Development of a 3D Finite Element Model of Thigh and Pelvis [Internet]. Warrendale, PA: SAE International; [cited 2015 Apr 24]. Available from: http://papers.sae.org/2004-01-2132/

Mergl C, Anton T, Madrid-Dusik R, Hartung J, Librandi A, Bubb H. 2004b. Development of a 3D Finite Element Model of Thigh and Pelvis [Internet]. Warrendale, PA: SAE International; [cited 2015 Apr 24]. Available from: http://papers.sae.org/2004-01-2132/ 
Mircheski I, Kandikjan T, Sidorenko S. 2014. Comfort Analysis of Vehicle Driver's Seat Through Simulation of the Sitting Process. Teh Vjesn-Tech Gaz. 21:291-298.

Moes, N. C. C. M., Horvath. 2002. Finite elements model of the human body: Geometry and non-linear material properties. Proc TMCE.:22-26.

Mohanty PP, Mahapatra SS. 2014. A finite element approach for analyzing the effect of cushion type and thickness on pressure ulcer. Int J Ind Ergon. 44:499-509.

Mooney M. 1940. A Theory of Large Elastic Deformation. J Appl Phys. 11:582-592.

Olesen CG, Zee M de, Rasmussen J. 2010a. Missing links in pressure ulcer research-An interdisciplinary overview. J Appl Physiol. 108:1458-1464.

Olesen CG, Zee M de, Rasmussen J. 2010b. Missing links in pressure ulcer research-An interdisciplinary overview. J Appl Physiol. 108:1458-1464.

Oomens CWJ, Bressers OFJT, Bosboom EMH, Bouten CVC, Bader DL. 2003. Can Loaded Interface Characteristics Influence Strain Distributions in Muscle Adjacent to Bony Prominences? Comput Methods Biomech Biomed Engin. 6:171-180.

Oomens CWJ, Loerakker S, Bader DL. 2010. The importance of internal strain as opposed to interface pressure in the prevention of pressure related deep tissue injury. J Tissue Viability. 19:35-42.

Oomens CWJ, Zenhorst W, Broek M, Hemmes B, Poeze M, Brink PRG, Bader DL. 2013a. A numerical study to analyse the risk for pressure ulcer development on a spine board. Clin Biomech. 28:736-742.

Oomens CWJ, Zenhorst W, Broek M, Hemmes B, Poeze M, Brink PRG, Bader DL. 2013b. A numerical study to analyse the risk for pressure ulcer development on a spine board. Clin Biomech. 28:736-742.

Oudenhuijzen A, Tan K, Morsch F. 2003. The Relationship Between Seat Pressure and Comfort [Internet]. Warrendale, PA: SAE International; [cited 2015 Mar 19]. Available from: http://papers.sae.org/2003-01-2213/

Palevski A, Glaich I, Portnoy S, Linder-Ganz E, Gefen A. 2006. Stress relaxation of porcine gluteus muscle subjected to sudden transverse deformation as related to pressure sore modeling. J Biomech Eng. 128:782-787.

Pankoke S, Siefert A. 2007. Virtual Simulation of Static and Dynamic Seating Comfort in the Development Process of Automobiles and Automotive Seats: Application of Finite-ElementOccupant-Model CASIMIR [Internet]. Warrendale, PA: SAE International; [cited 2015 Apr 24]. Available from: http://papers.sae.org/2007-01-2459/

Peterson MJ, Adkins HV. 1982. Measurement and Redistribution of Excessive Pressures During Wheelchair Sitting. Phys Ther. 62:990-994.

Reddy NP, Cochran GVB, Krouskop TA. 1981. Interstitial fluid flow as a factor in decubitus ulcer formation. J Biomech. 14:879-881.

Rivlin RS. 1948. Large Elastic Deformations of Isotropic Materials. In: Barenblatt GI, Joseph DD, editors. Collect Pap RS Rivlin [Internet]. [place unknown]: Springer New York; [cited 
2016 Dec 21]; p. 90-108. Available from: http://link.springer.com/chapter/10.1007/978-14612-2416-7_8

Sember J. 1994. The biomechanical relationship of seat design to the human anatomy. Hard Facts Soft Mach Ergon Seat.:221-230.

Silber, Then. 2009. Numerical Analysis of the Interactions between Human Body Soft Tissue and Body Supports.

Tang CY, Chan W, Tsui CP. 2010. Finite Element Analysis of Contact Pressures between Seat Cushion and Human Buttock-Thigh Tissue. Engineering. 02:720-726.

Tang CY, Tsui CP. 2006. Method of modeling muscular tissue with active finite elements [Internet]. [cited 2016 Mar 29]. Available from: http://ira.lib.polyu.edu.hk/handle/10397/137

Todd, Thacker. 1994. Three-dimensional computer model of the human buttocks, in vivo. J Rehabil Res Dev.:111-111.

Verver MM, van Hoof J, Oomens CWJ, Wismans JSHM, Baaijens FPT. 2004a. A Finite Element Model of the Human Buttocks for Prediction of Seat Pressure Distributions. Comput Methods Biomech Biomed Engin. 7:193-203.

Verver MM, van Hoof J, Oomens CWJ, Wismans JSHM, Baaijens FPT. 2004b. A Finite Element Model of the Human Buttocks for Prediction of Seat Pressure Distributions. Comput Methods Biomech Biomed Engin. 7:193-203.

Vink P. 2011. Aircraft Interior Comfort and Design. [place unknown]: CRC Press.

Vink P, Hallbeck S. 2012a. Editorial: Comfort and discomfort studies demonstrate the need for a new model. Appl Ergon. 43:271-276.

Vink P, Hallbeck S. 2012b. Editorial: Comfort and discomfort studies demonstrate the need for a new model. Appl Ergon. 43:271-276.

Volpe Y, Governi L, Furferi R. 2015. A Computational Model for Early Assessment of Padded Furniture Comfort Performance. Hum Factors Ergon Manuf Serv Ind. 25:90-105.

Wagnac EL, Aubin C-E, Dansereau J. 2008a. A New Method to Generate a Patient-Specific Finite Element Model of the Human Buttocks. IEEE Trans Biomed Eng. 55:774-783.

Wagnac EL, Aubin C-E, Dansereau J. 2008b. A New Method to Generate a Patient-Specific Finite Element Model of the Human Buttocks. IEEE Trans Biomed Eng. 55:774-783.

Wenyu W, Chenqi X, Lindong L. 2013. Characteristic parameters of cushion in high-speed train $(\mathrm{CRH})$ contribute to seat pressure distribution analysis. In: Zhao H, Liu K, Yu X, editors. Adv Des Manuf Technol lii Pts 1-4. Vol. 397-400. Stafa-Zurich: Trans Tech Publications Ltd; p. 593-598.

Xiaoming D, Jindong R, Chunlei S, Lemeng L. 2013. Simulation of the Interaction between Driver and Seat. Chin J Mech Eng. 26:1234-1242.

Zemp R, Taylor WR, Lorenzetti S. 2015. Are pressure measurements effective in the assessment of office chair comfort/discomfort? A review. Appl Ergon. 48:273-282. 
Zhang M, Zheng YP, Mak AFT. 1997. Estimating the effective Young's modulus of soft tissues from indentation tests-nonlinear finite element analysis of effects of friction and large deformation. Med Eng Phys. 19:512-517. 


\section{Tables}

Table 1 : Geometry of the FE models for assessing seat discomfort (star $\left({ }^{*}\right)$ indicates a full-body model and double star $(* *)$ indicates geometries coming from different sources)

\begin{tabular}{|c|c|c|c|c|c|c|c|}
\hline & Study & $2 D / 3 D$ & Composition & $\begin{array}{l}\text { Source of } \\
\text { geometry }\end{array}$ & Number of elements & $\begin{array}{l}\text { Population } \\
\text { category }\end{array}$ & $\begin{array}{l}\text { Model } \\
\text { Outputs }\end{array}$ \\
\hline 1 & $\begin{array}{l}\text { (Brosh \& Arcan } \\
2000)\end{array}$ & $2 \mathrm{D}$ & $\begin{array}{l}\text {-Bones: Pelvis } \\
\text {-Soft tissues: undifferentiated }\end{array}$ & CT-scan** & $/ /$ & // & Internal stress \\
\hline 2 & (Moes et al. 2002) & $3 \mathrm{D}$ & $\begin{array}{l}\text {-Bones: femur, sacrum and } \\
\text { pelvis } \\
\text {-Soft tissues: undifferentiated }\end{array}$ & $\begin{array}{l}\text { Pictures of } \\
\text { slices (Visible } \\
\text { Human)** }\end{array}$ & Hexahedral elements & 77-kg male & Contact Pressure \\
\hline 3 & $\begin{array}{l}\text { (Mergl et al. } \\
\text { 2004a) }\end{array}$ & $3 D$ & $\begin{array}{l}\text {-Bones: femur, sacrum and } \\
\text { pelvis } \\
\text {-Soft tissues: undifferentiated }\end{array}$ & CT-scan** & 53510 tetrahedral elements & $50^{\text {th }}$ percentile male & $\begin{array}{l}\text { Contact Pressure } \\
\text { and internal } \\
\text { stress }\end{array}$ \\
\hline 4 & $\begin{array}{l}\text { (Verver et al. } \\
\text { 2004b) }\end{array}$ & $3 \mathrm{D}$ & $\begin{array}{l}\text {-Bones: femur, sacrum and } \\
\text { pelvis } \\
\text {-Soft tissues: undifferentiated }\end{array}$ & $\begin{array}{r}\text { Pictures of } \\
\text { slices (HUMOS) }\end{array}$ & $\begin{array}{l}158310 \text { elements (tetrahedral } \\
\text { elements for soft tissues and } \\
\text { triangular shells for skin and } \\
\text { bones) }\end{array}$ & $\begin{array}{l}\text { HUMOS subject } \\
(173 \mathrm{~cm}, 80 \mathrm{~kg})\end{array}$ & Contact Pressure \\
\hline 5 & (Choi et al., 2007) & $3 D^{*}$ & $\begin{array}{l}\text {-Bones: head, neck, full spine, } \\
\text { thorax, pelvis with sacrum, } \\
\text {-Soft tissues : Skin and flesh }\end{array}$ & CT-scan** & Tetrahedral elements & $\begin{array}{l}\text { One } 5^{\text {th }}, \text { one } 50^{\text {th }} \\
\text { and one } 95^{\text {th }} \\
\text { percentile }\end{array}$ & Contact Pressure \\
\hline 6 & $\begin{array}{l}\text { (Cheng et al. } \\
\text { 2007) }\end{array}$ & $3 \mathrm{D}$ & $\begin{array}{l}\text {-Bones: femur, sacrum and } \\
\text { pelvis } \\
\text {-Soft tissues: Skin and flesh }\end{array}$ & 3d Scan** & // & $50^{\text {th }}$ percentile male & $\begin{array}{l}\text { Contact } \\
\text { Pressure }\end{array}$ \\
\hline 7 & $\begin{array}{l}\text { (Pankoke \& } \\
\text { Siefert 2007) }\end{array}$ & $3 D^{*}$ & $\begin{array}{l}\text {-Bones: Pelvis, femur, tibia, } \\
\text { cervical spine, head and arms } \\
\text {-Soft tissues: flesh in contact } \\
\text { regions (around thigh and } \\
\text { pelvis) and abdominal and } \\
\text { dorsal musculature }\end{array}$ & $\begin{array}{l}\text { Pictures of } \\
\text { slices (Visible } \\
\text { Human) }\end{array}$ & Tetrahedral elements & $\begin{array}{l}5^{\text {th }}, \text { one } 50^{\text {th }} \text { and } \\
\text { one } 95^{\text {th }} \text { percentile }\end{array}$ & Contact Pressure \\
\hline 8 & $\begin{array}{l}\text { (Grujicic et al. } \\
\text { 2009b) }\end{array}$ & $3 D^{*}$ & $\begin{array}{l}\text {-Bones: pelvis } \\
\text {-Soft tissues: skin and flesh }\end{array}$ & $\begin{array}{l}\text { 3dcadbrowser } \\
\text { database** }\end{array}$ & $\begin{array}{l}\text { Skin: } 60000 \text { 3-node shells } \\
\text { Soft tissues: } 1350004 \text {-node } \\
\text { tetrahedral elements }\end{array}$ & $/ /$ & $\begin{array}{l}\text { Contact Pressure } \\
\text { and internal } \\
\text { stress }\end{array}$ \\
\hline
\end{tabular}


Bones:30 000 3-node shell

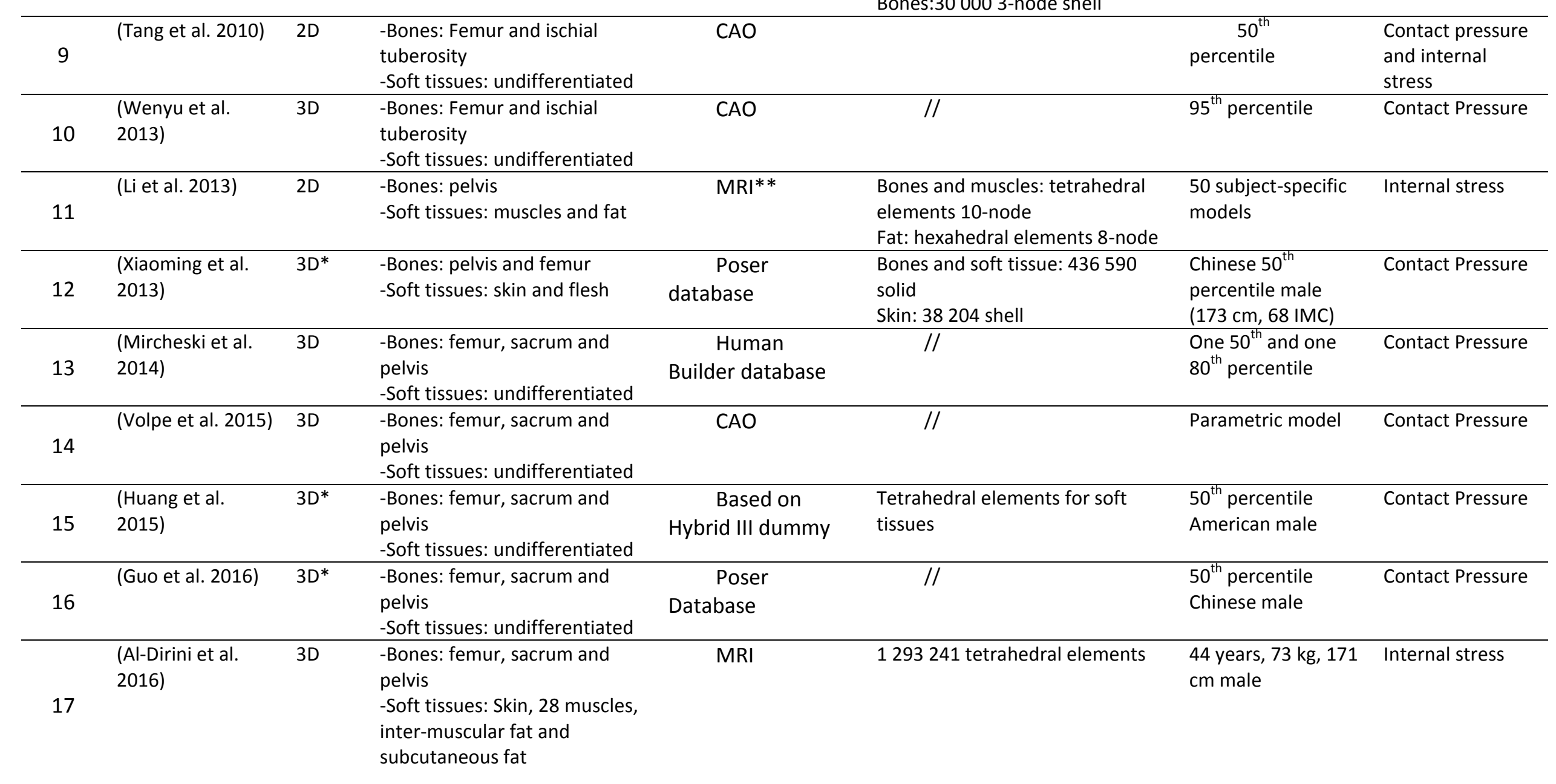


Table 2: Geometry of the FE models for investigating pressure ulcer development (star $\left({ }^{*}\right)$ indicates a full-body model and double star $(* *)$ indicates geometries coming from different sources)

\begin{tabular}{|c|c|c|c|c|c|c|c|}
\hline & Study & $2 D / 3 D$ & Composition & $\begin{array}{r}\text { Source } \\
\text { of geometry }\end{array}$ & Number of elements & $\begin{array}{l}\text { Population } \\
\text { category }\end{array}$ & Application \\
\hline 18 & $\begin{array}{l}\text { (Todd \& Thacker } \\
\text { 1994) }\end{array}$ & $2 \mathrm{D}$ & $\begin{array}{l}\text {-Bones: Ischial tuberosity } \\
\text {-Soft tissues: undifferentiated }\end{array}$ & MRI & 1008 hexahedral elements & $\begin{array}{l}\text { One } 58-k g \text { female and } \\
\text { one } 74-\mathrm{kg} \text { male }\end{array}$ & $\begin{array}{l}\text { Soft tissue } \\
\text { displacement and } \\
\text { stress }\end{array}$ \\
\hline 19 & (Lin et al. 2004) & $2 \mathrm{D}$ & $\begin{array}{l}\text {-Soft tissues: Epidermis, dermis, } \\
\text { fat and muscle }\end{array}$ & CAO & Hexahedral element & $/ /$ & $\begin{array}{l}\text { Soft tissue strain and } \\
\text { stress }\end{array}$ \\
\hline 20 & $\begin{array}{l}\text { (Kuroda \& } \\
\text { Akimoto 2005) }\end{array}$ & $2 \mathrm{D}$ & -Soft tissues: undifferentiated & CAO & 576 Hexahedral elements & & Soft tissue stress \\
\hline 21 & $\begin{array}{l}\text { (Linder-Ganz, et } \\
\text { al. 2007) }\end{array}$ & $2 \mathrm{D}$ & $\begin{array}{l}\text {-Bones: pelvis } \\
\text {-Soft tissues: fat and skin } \\
\text { together, gluteus muscle and } \\
\text { other muscles }\end{array}$ & MRI & $\begin{array}{l}28948 \text {-node hexahedral elements } \\
\text { for gluteus muscle } \\
488 \text { 8-node hexahedral elements } \\
\text { for other muscle } \\
3688 \text { 8-node hexahedral } \\
\text { elements for fat and skin }\end{array}$ & $\begin{array}{l}6 \text { subject around } 50^{\text {th }} \\
\text { percentile }\end{array}$ & $\begin{array}{l}\text { Soft tissue strain and } \\
\text { stress }\end{array}$ \\
\hline 22 & $\begin{array}{l}\text { (Makhsous et al. } \\
\text { 2007a) }\end{array}$ & $3 \mathrm{D}$ & $\begin{array}{l}\text { - Bones: femur and pelvis, } \\
\text { - Soft tissues: skin, fat and five } \\
\text { muscle groups }\end{array}$ & MRI & $\begin{array}{l}453502 \text { 4-node tetrahedral solid } \\
\text { elements } \\
\text { Skin: } 33924 \text { 3-node triangle } \\
\text { membrane elements }\end{array}$ & $\begin{array}{l}24 \text { years, } 165 \mathrm{~cm}, 70 \\
\text { kg male }\end{array}$ & $\begin{array}{l}\text { Soft pressure and } \\
\text { stress }\end{array}$ \\
\hline 23 & $\begin{array}{l}\text { (Wagnac et al. } \\
2008 b \text { ) }\end{array}$ & $3 \mathrm{D}$ & $\begin{array}{l}\text { - Bones: pelvis } \\
\text {-Soft tissues: undifferentiated }\end{array}$ & $\begin{array}{r}\text { CT- } \\
\operatorname{scan}^{* *}\end{array}$ & $\begin{array}{l}292924 \text {-nodes tetrahedral } \\
\text { elements }\end{array}$ & $\begin{array}{l}24 \text { years, } 75 \mathrm{~kg}, 180 \\
\mathrm{~cm}\end{array}$ & $\begin{array}{l}\text { Soft tissue strain and } \\
\text { stress }\end{array}$ \\
\hline 24 & $\begin{array}{l}\text { (Oomens et al., } \\
\text { 2013) }\end{array}$ & $2 \mathrm{D}$ & $\begin{array}{l}\text {-Bones: pelvis, } \\
\text {-Soft tissues: skin, muscles and } \\
\text { fat }\end{array}$ & MRI & $/ /$ & $\begin{array}{l}3 \text { female models: } \\
(159 \mathrm{~cm}, 49 \\
\mathrm{kg})(172 \mathrm{~cm}, 68 \mathrm{~kg})(168 \\
\mathrm{cm}, 77 \mathrm{~kg})\end{array}$ & Soft tissue strain \\
\hline 25 & (Levy et al. 2014) & $2 \mathrm{D}$ & $\begin{array}{l}\text {-Bones: pelvis, } \\
\text {-Soft tissues: skin, muscles and } \\
\text { fat }\end{array}$ & MRI & $\begin{array}{l}\text { Tetrahedral elements } \\
\text { Skin:9248 } \\
\text { Fat: } 27895 \\
\text { Muscle: } 6640 \\
\text { Bone:2103 } \\
\end{array}$ & Male: 27 years, 90 kg & Soft tissue stress \\
\hline 26 & $\begin{array}{l}\text { (Mohanty \& } \\
\text { Mahapatra 2014) }\end{array}$ & $2 \mathrm{D}$ & $\begin{array}{l}\text {-Bones: ischial tuberosity } \\
\text {-Soft tissues: undifferentiated }\end{array}$ & MRI & $/ /$ & $55 \mathrm{~kg}$ male & ssue stress \\
\hline
\end{tabular}


(Luboz et al.

Table 3:Material properties for the soft tissues of the FE models

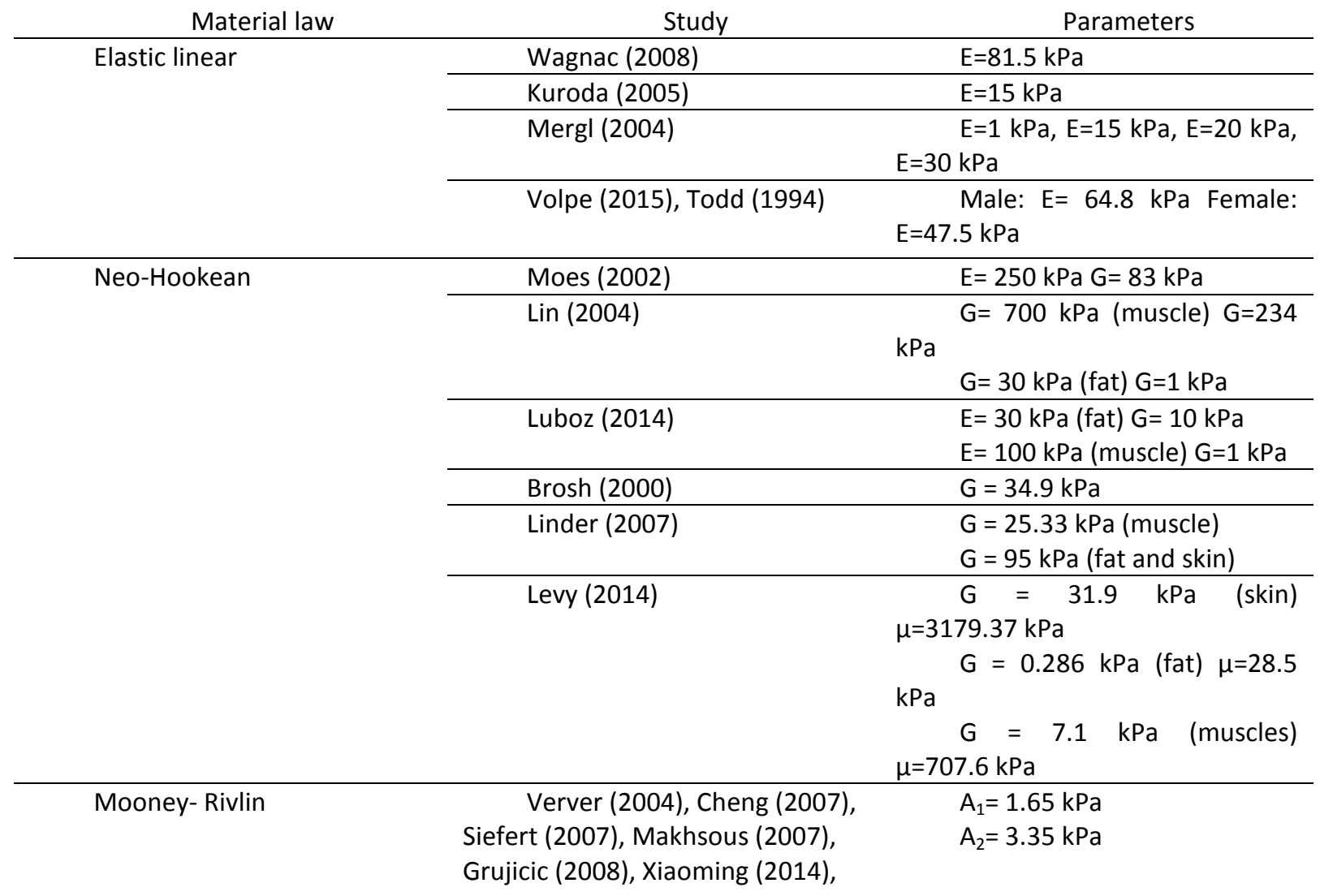


Mircheski (2014), Huang(2015),

Guo (2016)

Generalized Rivlin (2 ${ }^{\text {nd }}$ order)

Tang (2010), Mohanty (2014)

$\mathrm{C}_{10}=0.08556, \mathrm{C}_{01}=-0.05841$,

$C_{20}=0.039, C_{11}=-0.02319$,

$C_{02}=0.00851, D_{1}=3.65273, D_{2}=0$

Ogden

Li (2013) ( $2^{\text {nd }}$ order $)$

Fat: $\alpha 1=-0.107647, \mu 1=$

$0.118261 \mathrm{e}-2, \alpha 2=-0.318953, \mu 2=$

$0.643855 \mathrm{e}-7$

Muscle: $\alpha 1=0.1316402 \mathrm{e}+1$

$\mu 1=0.10257 \mathrm{e}-2, \quad \alpha 2=$

$0.1835933 e+2, \mu 2=0145209 \mathrm{e}-6$

Oomens (2013) ( $1^{\text {st }}$ order)

Skin: $\mu=8 \mathrm{kPa} \quad \alpha=5$

Fat: $\mu=1 \mathrm{kPa}$

$\alpha=5$

Muscle: $\mu=0.3 \mathrm{kPa} \quad \alpha=5$

Al Dirini (2016) (1 $1^{\text {st }}$ order $)$

Fat and skin: $\mu=1.17 \mathrm{kPa} \alpha$

$=16.2$

Muscles: $\mu=1.91 \mathrm{kPa}$

$=4.6$ 
Table 4:Error percentage between simulated and measured pressure in Mergl et al; Verver (2004); Mircheski (2014); Volpe (2014); Wagnac (2008); Li (2013)

\begin{tabular}{llrrrrr} 
& Mergl (2004) & $\begin{array}{l}\text { Verver } \\
(2004)\end{array}$ & $\begin{array}{l}\text { Mircheski } \\
\text { (2014) }\end{array}$ & $\begin{array}{l}\text { Volpe } \\
(2014)\end{array}$ & $\begin{array}{l}\text { Wagnac } \\
(2008)\end{array}$ & Li (2013) \\
\hline $\mathrm{P}_{\max }$ (\%err) & $2 \%$ & $37 \%$ & $2 \%$ & $9 \%$ & $9 \%$ & $5 \%$ \\
\hline $\mathrm{P}_{\text {mean }}$ (\%err) & $11 \%$ & $44 \%$ & & $7 \%$ & $31 \%$ &
\end{tabular}

Table 5:Contact area, mean pressure, peak pressure and peak Von Mises stress in the tissues under the ischial tuberosities simulated using the 8 models combining different geometrical details and material behavioral laws

\begin{tabular}{|c|c|c|c|c|c|c|}
\hline & & & Area $\mathrm{cm}^{2}$ & $\begin{array}{l}\text { Pmean } \\
\mathrm{kPa}\end{array}$ & $\begin{array}{l}\text { Pmax } \\
\mathrm{kPa}\end{array}$ & $\begin{array}{l}\text { Von Mises Stress max } \\
\text { kPa }\end{array}$ \\
\hline Model & Mesh & Linear & & & & \\
\hline 1 & 1 & elastic & 187 & 17,7 & 41,6 & 44,5 \\
\hline Model & Mesh & Neo- & & & & \\
\hline 2 & 1 & Hookean & 209 & 15,8 & 88,9 & 27,0 \\
\hline Model & Mesh & Moon & & & & \\
\hline 3 & 1 & ey Rivlin & 253 & 13,0 & 65,7 & 50,0 \\
\hline Model & Mesh & Linear & & & & \\
\hline 4 & 2 & elastic & 212 & 15,6 & 40,4 & 41,8 \\
\hline Model & Mesh & Neo- & & & & \\
\hline 5 & 2 & Hookean & 235 & 14,0 & 76,7 & 26,9 \\
\hline Model & Mesh & Moon & & & & \\
\hline 6 & 2 & ey Rivlin & 253 & 13,0 & 59,3 & 50,0 \\
\hline Model & Mesh & Neo- & & & & \\
\hline 7 & 3 & Hookean & 259 & 12,8 & 90,4 & 32,8 \\
\hline Model & Mesh & Neo- & & & & \\
\hline 8 & 4 & Hookean & 310 & 10,7 & 90,0 & 25,0 \\
\hline
\end{tabular}




\section{Figures}

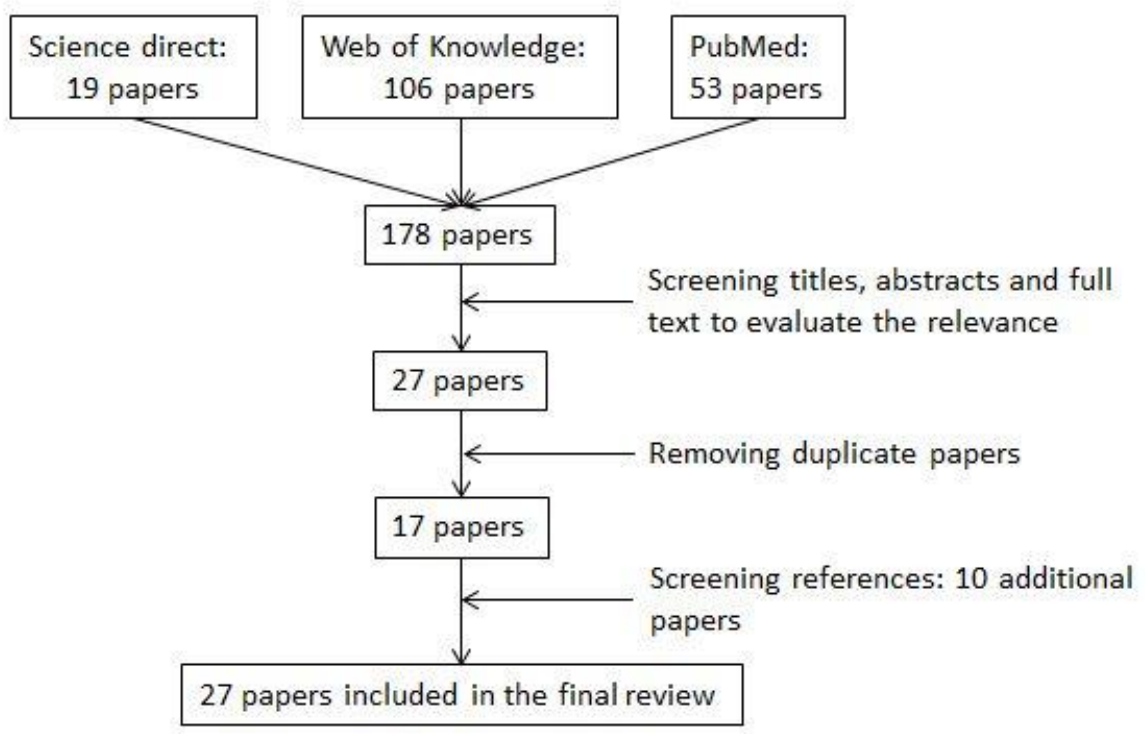

Figure 1: Flow Chart of the literature search 